\title{
Observations on the collection and handling of blood samples for N.E.F.A. estimation
}

\author{
D. V. I. FAIRWEATHER ${ }^{1}$ AND R. LAYTON \\ From the Department of Obstetrics and Gynaecology, University of Newcastle upon Tyne
}

SYNOPSIS The effect upon the results of estimating plasma or serum non-esterified fatty acids (N.E.F.A.) assay by different methods of collecting blood samples and subsequent differences in sample storage and time of assay have been studied. Standardization of technique is advised and the use of chilled heparinized tubes, with separation of the sample within one hour of collection and assay on the day of collection is advocated.

The estimation of plasma or serum non-esterified fatty acids (N.E.F.A.) has been undertaken by many workers studying the factors controlling mobilization of body fat. Evaluation and comparison of results is complicated by the fact that many different techniques are used for the estimations (Nelson, 1965). Apart from differences in technique between investigators differences in mode of collection and handling of the blood samples is also apparent.

Some workers (Gordon, 1961; Fairweather, 1965) use serum but most use plasma. The anticoagulant used is sometimes heparin (Carlson and Wadström, 1958; Hales and Randle, 1963) and sometimes oxalate (Mendelsohn, 1958; Havel and Goldfien, 1959; Gordon, 1957). Collection of the specimen into tubes at $0^{\circ} \mathrm{C}$. (Carlson and Wadström, 1958), at room temperature, or even the use of chilled syringes (Grossman, Palm, Becker, and Moeller 1954) has been advised. Immediate centrifugation is the rule in most cases and some workers (Svanborg and Svennerholm, 1958; Carlson and Wadström, 1958; Havel and Goldfien, 1959) use a refrigerated centrifuge. The performance of the assay on the day of collection is stressed by some workers (Hales and Randle, 1963). Delay in performing the assay is not mentioned frequently but it was noticed by Davis (1947) that storage of a refrigerated specimen of serum resulted in a rise in N.E.F.A. level and $\mathrm{Gabr}$, Mansour, and Amin (1966) noted a fourfold rise in plasma N.E.F.A. after storage of the samples for six months at room temperature.

Although most workers seem to have very precise techniques for the handling of specimens it is rarely if ever made clear why such techniques are necessary. It was decided therefore, using a standard technique ${ }^{1}$ Present address University College Hospital, Obstetric Hospital, Huntley Street, London W.C.1.

Received for publication 12 January 1967. for N.E.F.A. estimation, to evaluate the effect upon the end result of different methods of handling the blood specimens.

\section{MATERIALS AND METHODS}

The technique of N.E.F.A. estimation used was a modification (Fairweather, 1965) of the Dole technique (1956) using Nile Blue $\mathbf{A}$ as the indicator. The titration was performed using a micrometer syringe. In experienced hands this technique gave less than $10 \%$ experimental error. The strength of the alkali solution used in the titration affected the (standard-blank) value which if low was liable to exaggerate any experimental error. The optimal strength of the alkali was found to be a dilution of one part saturated solution of $\mathrm{NaOH}$ in 1,250 parts of $\mathrm{CO}_{2-}$ free water. This gave a satisfactory standard-blank value and at the same time a precise end-point to the titration.

The specimens were collected from patients in a maternity hospital at the time of routine investigations in the puerperium or at the antenatal clinic. In most cases the patients were not starved or prepared in any other way. From each patient about $12 \mathrm{ml}$. of blood was removed and divided into two portions, each portion being treated separately. A total of 91 specimens were collected.

Comparisons were made of specimens collected into plain tubes and tubes containing heparin at room temperature. This comparison was then repeated with prior chilling of specimen tubes in iced water. Then, using the heparinized tubes, a comparison was made of the specimen collected into tubes at room temperature and tubes in iced water. Finally a small group was compared, in the one case using plain tubes at room temperature and in the other heparinized tubes in iced water. In all these tests the specimens after collection were treated in a similar manner, being centrifuged at room temperature within one hour of collection and assayed on the same day.

The effect of delay in separation of the plasma was investigated using chilled heparinized specimens, one 
being separated within one hour and the other being separated 24 hours after collection.

The effects of delay in assay after separation was investigated by performing the assay on the day of collection and again 24 hours later. The assay was repeated in the second set four days later. The stored specimens were kept at $4^{\circ} \mathrm{C}$. between assays.

\section{RESULTS}

The differences in results between assays carried out on serum and plasma from the same patients are shown in Table I for specimens collected into tubes at room temperature and in Table II for specimens collected into chilled tubes.

\section{TABLE I}

SPECIMENS COLLECTED INTO PLAIN AND HEPARINIZED TUBES AT ROOM TEMPERATURE

N.E.F.A. Expressed as $\mu$ Eq./l.

\begin{tabular}{llll}
\hline $\begin{array}{l}\text { Plain Tube } \\
\text { (serum) }\end{array}$ & $\begin{array}{l}\text { Heparin Tube } \\
\text { (plasma) }\end{array}$ & Difference & $\begin{array}{l}\text { Plasma Result } \\
\text { Expressed as } \\
\text { Percentage of } \\
\text { Serum Result }\end{array}$ \\
\hline 372 & & & $95 \cdot 2$ \\
504 & 354 & -18 & $96 \cdot 6$ \\
398 & 487 & -17 & $77 \cdot 9$ \\
664 & 310 & -88 & $95 \cdot 9$ \\
841 & 637 & -27 & $94 \cdot 6$ \\
973 & 796 & -45 & $92 \cdot 8$ \\
489 & 903 & -70 & 91.6 \\
476 & 448 & -41 & 88.4 \\
696 & 421 & -55 & $94 \cdot 1$ \\
372 & 655 & -41 & 96.5 \\
517 & 359 & -13 & 98.6 \\
Using the sign test ${ }^{1} \mathrm{P}$ & 0.001 & -7 & \\
& & & Mean 92.9 \\
(Siegel, 1956) & & &
\end{tabular}

TABLE II

SPECIMENS COLLECTED INTO CHILLED PLAIN AND HEPARINIZED (CHILLING IN ICE WATER) TUBES

N.E.F.A. Expressed as $\mu$ Eq./l.

\begin{tabular}{llll}
\hline $\begin{array}{l}\text { Plain Tube } \\
\text { Serum) }\end{array}$ & $\begin{array}{l}\text { Heparin Tube } \\
\text { (Plasma) }\end{array}$ & Difference & $\begin{array}{l}\text { Plasma Result } \\
\text { Expressed as } \\
\text { Percentage of } \\
\text { Serum Result }\end{array}$ \\
\hline 365 & & & $95 \cdot 3$ \\
408 & 348 & -17 & $64 \cdot 0$ \\
782 & 261 & -147 & $88 \cdot 4$ \\
217 & 691 & -91 & 88.0 \\
365 & 191 & -26 & $95 \cdot 3$ \\
583 & 348 & -17 & $92 \cdot 4$ \\
221 & 539 & -44 & $67 \cdot 4$ \\
377 & 149 & -72 & 93.6 \\
426 & 353 & -24 & 70.4 \\
& 300 & -126 & \\
Sign test $P=0.002$ & & Mean 83.9
\end{tabular}

The effects of chilling the specimen are shown in Table III and the difference between assay results using unchilled serum and chilled plasma is demonstrated in Table IV.
The effects of delay in separation of the plasma before assay are shown in Table $\mathrm{V}$.

The effect of 24 hours' delay in performing the assay is shown in Figure 1. Figure 2 shows the effect of four days' delay in performing the assay.

TABLE III

HEPARINIZED SPECIMEN COLLECTED IN TUBES AT ROOM TEMPERATURE AND IN CHILLED TUBES (CHILLING IN ICE WATER)

N.E.F.A. Expressed in $\mu$ Eq./l.

\begin{tabular}{|c|c|c|c|}
\hline $\begin{array}{l}\text { Unchilled } \\
\text { Plasma }\end{array}$ & $\begin{array}{l}\text { Chilled } \\
\text { Plasma }\end{array}$ & Difference & $\begin{array}{l}\text { Chilled Sample } \\
\text { Result Expressed } \\
\text { as Percentage } \\
\text { of Unchilled } \\
\text { Sample Result }\end{array}$ \\
\hline 496 & 289 & -207 & $58 \cdot 3$ \\
\hline 298 & 281 & -17 & $94 \cdot 3$ \\
\hline 231 & 223 & -8 & 96.5 \\
\hline 529 & 517 & -12 & $96 \cdot 8$ \\
\hline 421 & 364 & -57 & $86 \cdot 5$ \\
\hline 314 & 207 & -107 & $65 \cdot 9$ \\
\hline 347 & 322 & -25 & $92 \cdot 8$ \\
\hline 322 & 314 & -8 & $97 \cdot 5$ \\
\hline 603 & 529 & -74 & $87 \cdot 7$ \\
\hline 528 & 380 & -148 & $72 \cdot 0$ \\
\hline 1033 & 1017 & -16 & $98 \cdot 4$ \\
\hline 401 & 340 & -61 & $84 \cdot 8$ \\
\hline 659 & 612 & -47 & $92 \cdot 9$ \\
\hline 557 & 306 & -251 & $54 \cdot 9$ \\
\hline 598 & 557 & -41 & $93 \cdot 1$ \\
\hline \multicolumn{2}{|c|}{ Sign test $P=<0.001$} & \multicolumn{2}{|c|}{ Mean 84.8} \\
\hline
\end{tabular}

TABLE IV

SPECIMEN COLLECTED IN PLAIN TUBES AT ROOM TEMPERATURE AND IN CHILLED HEPARINIZED TUBES

N.E.F.A. Expressed in $\mu$ Eq./l.

\begin{tabular}{llll}
$\begin{array}{l}\text { Unchilled Plain } \\
\text { (Serum) }\end{array}$ & $\begin{array}{l}\text { Chilled Heparin } \\
(\text { Plasma })\end{array}$ & Difference & $\begin{array}{l}\text { Chilled Plasma } \\
\text { Result Expressed } \\
\text { as Percentage } \\
\text { of Unchilled } \\
\text { Serum Result }\end{array}$ \\
& & & \\
\hline 559 & & & $72 \cdot 8$ \\
483 & 407 & -152 & $31 \cdot 7$ \\
754 & 153 & -330 & $45 \cdot 0$ \\
668 & 339 & -415 & $40 \cdot 6$ \\
686 & 271 & -397 & $61 \cdot 8$ \\
458 & 424 & -262 & $62 \cdot 9$ \\
689 & 288 & -170 & $84 \cdot 6$ \\
403 & 583 & -106 & $37 \cdot 5$ \\
1317 & 151 & -252 & $87 \cdot 5$ \\
472 & 1152 & -165 & $97 \cdot 2$ \\
741 & 459 & -13 & $49 \cdot 5$ \\
529 & 367 & -374 & $42 \cdot 5$ \\
283 & 225 & -304 & $85 \cdot 8$ \\
348 & 206 & -77 & \\
& 296 & -52 & \\
Sign test P $=0.001$ & & & Mean $62 \cdot 25$
\end{tabular}

DISCUSSION

From the results presented it will be noted that the difference between serum and plasma N.E.F.A. levels 8 
TABLE V

CHILLED HEPARINIZED SPECIMEN SEPARATED WITHIN ONE HOUR AND AT 24 HOURS

N.E.F.A. Expressed in $\mu E q . / l$.

\begin{tabular}{llll}
\hline $\begin{array}{l}\text { Separated } \\
\text { Under 1 Hour }\end{array}$ & $\begin{array}{l}\text { Separated in } \\
24 \text { Hours }\end{array}$ & Difference & $\begin{array}{l}\text { Difference } \\
\text { Expressed as } \\
\text { Percentage of } \\
\text { Result at under } \\
\text { 1 hour }\end{array}$ \\
& & & $36 \cdot 0$ \\
\hline 400 & & & $48 \cdot 0$ \\
300 & 544 & +144 & $114 \cdot 4$ \\
320 & 444 & +144 & $44 \cdot 3$ \\
576 & 686 & +366 & $35 \cdot 5$ \\
888 & 831 & +255 & $31 \cdot 1$ \\
504 & 1203 & +315 & $41 \cdot 9$ \\
386 & 661 & +157 & $143 \cdot 5$ \\
660 & 548 & +162 & $-27 \cdot 1$ \\
660 & 1607 & +947 & $8 \cdot 6$ \\
613 & 481 & -179 & $46 \cdot 4$ \\
440 & 666 & +53 & $108 \cdot 9$ \\
450 & 644 & +204 & \\
& 940 & +490 &
\end{tabular}

Sign test $\mathbf{P}=0.003$

Mean 52.6

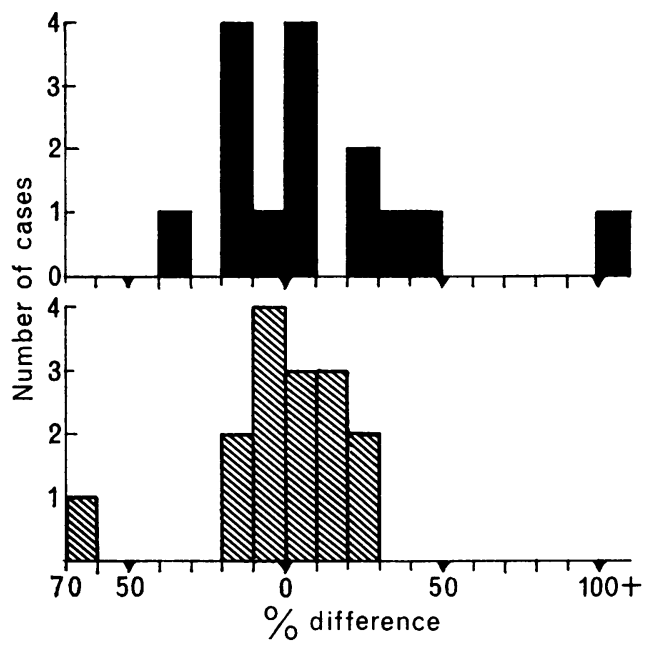

FIGS. 1 and 2. Figure 1 (top) shows the effect of 24 hours' delay and Fig. 2(bottom) that of four days'delay in performing the assay.

is significant whether the specimens are collected at $0^{\circ} \mathrm{C}$. or at room temperature. It is interesting that although the actual differences in most cases lie within the $10 \%$ experimental variation of the test the serum levels are consistently higher. From the practical point of view it should be noted that plasma is easier than serum to handle for assay purposes.

The effect of chilling is also clearly significant and in all the tests the chilled specimen gave lower readings. Again in most cases the differences were slight. It has also been shown that the effects may be combined. Those assays carried out on unchilled serum compared with those performed on chilled plasma produced a very striking difference in the N.E.F.A. result.

Although it is not within the scope of this paper to discuss why these differences occur or to evaluate in absolute terms which value is correct, it was felt that to obtain practical reproducible results a chilled heparinized specimen was preferable.

The delay in scparation of the sample also produced a significant and very consistent effect upon the result. The differences here are large and on three occasions the effect of the delay was to more than double the result. There seems little doubt that immediate separation is vital to avoid erroneous values and ensure reproducible results.

The effects of delay in performing the assay after separation of the sample were extremely variable and as shown by the sign test the differences are not significant when considered as a group. However, it is interesting to note that a delay of 24 hours resulted in one case in the doubling of the result and in one case after four days a fall in the result of $64 \%$.

From the evidence of these results it is considered that whenever possible the assay for N.E.F.A. should be performed on the day the sample is collected. If for any reason this is not possible it would be reasonable to accept the result of assay performed within the next few days provided that the sample was separated within one hour of collection and kept in refrigeration $\left(4^{\circ} \mathrm{C}\right)$. However, it seems that there is little difference between the results of assays carried out after 24 hours or after four days provided that the separated sample is stored at $4^{\circ} \mathrm{C}$.

The authors gratefully acknowledge the technical assistance of Miss P. Charlton and Miss J. Mason in the above study.

\section{REFERENCES}

Carlson, L. A., and Wadström, L. B. (1958). Scand. J. clin. Lab. Invest., 10, 407.

Davis, B. D. (1947). Arch. Biochem., 15, 351.

Dole, V. P. (1956). J. clin. Invest., 35, 150.

Fairweather, D. V. I. (1965). J. Obstet. Gynaec. Brit. Cwlth, 72, 408.

Gabr, Y., Mansour, F., and Amin, N. (1966). Lancet, 2, 196.

Gordon, R. S. Jr. (1957). J. clin. Invest., 36, 810.

(1961). In Lipids and the Steroid Hormones in Clinical Medicine, edited by F. W. Sunderman and F. W. Sunderman, Jr., p. 43. Lippincott, Philadelphia. Pitman, London

Grossman, M. I., Palm, L., Becker, G. H., and Moeller, H. C. (1954). Proc. Soc. exp. Biol. (N.Y.), 87, 312.

Hales, C. N., and Randle P. J. (1963). Lancet, 1, 790.

Havel, R. J., and Goldfien A. (1959). J. Lipid Res., 1, 102.

Mendelsohn, D. (1958). S. Afr. J. med. Sci., 23, 75.

Nelson, G. H. (1965). Amer. J. Obstet. Gynec., 92, 202.

Siegel, S. (1956). Non Parametric Statistics for the Behavioral Sciences, p. 68. McGraw Hill, New York.

Svanborg, A., and Svennerholm, L. (1958). Clin chim. Acta, 3, 443. 